\title{
The Great Kansas Seed Swindle
}

\author{
M.H. Hoeflich
}

In February, 1885, the Kansas legislature approved a law that made it a misdemeanor punishable by a fine of "not less than ten dollars nor more than two hundred dollars, or by imprisonment in a county jail not less than thirty days nor more than six months" to "misrepresent, deceive or defraud any person ... in the sale of any fruit, shade or ornamental tree . . . or any vine, shrub, plant, bulb, or root." As with all legislation this specific, there is quite a fascinating story behind this law, one worth recounting.

By 1885, Lawrence, Kansas had moved from the status of a rough frontier town to a civilized settlement of stately homes, with a school, multiple churches, a thriving mercantile district, and even the state university. In just thirty years the people of Lawrence and Douglas County had made their city a showplace of Western civilization and culture. As has always been true of such places, the women residents of Lawrence had been particularly instrumental in civilizing the place. The age of quickly thrown-together rough cabins was over. By 1885, the City of Lawrence was a good place to raise a family and run a business. The men and women of Lawrence were devoted not only to culture but also to the horticultural arts. From contemporary portraits and etchings of the city it is clear that a beautification effort was well underway.

Unfortunately the latter quarter of the nineteenth century was also a period in which swindles and confidence tricks were endemic. As Professor Karen Haltunnen has written, this was a period of both population growth and national expansion. ${ }^{2}$ The days of small villages when everyone knew everyone else were over. Strangers were a

\footnotetext{
* John H. \& John M. Kane Distinguished Professor of Law, University of Kansas School of Law; Courtesy Professor of History, University of Kansas. A version of this Article was delivered as the after-dinner lecture at the 2006 Annual Meeting of the Douglas County Historical Society in November, 2006.

1. See Act of Feb. 19, 1886, ch. 100, 1886 Kan. Sess. Laws of Spec. Sess. 136 (titled "AN ACT to punish misrepresentation and deception in the sale of fruit, shade or ornamental trees, vines, shrubs, plants, bulbs, and roots").

2. Karen Haltunnen, Confidence Men and Painted Women 1 (1982). Of course, the greatest contemporary illustration of this is HERMAN MELVILLE, THE CONFIDENCE-MAN: HIS MASQUERADE (Grove Press 1949) (1857).
} 
common sight in America's cities. Many were commercial agents. In the West, in particular, commercial agents sold everything from books to pans, including seeds, plants, and trees. This was also a period in which the printing industry had made great leaps forward in techniques, particularly in color printing by chromolithography. ${ }^{3}$ This made the latter decades of the nineteenth century the heyday of extravagant catalogues. Among the most extravagant of these various seductive volumes were those put out by nurseries offering plants and trees for sale. Even at more than a century's distance, one can look at these catalogues with their gorgeous horticultural illustrations and feel an urge to purchase the plants so illustrated.

To understand the great temptation these catalogues offered to the citizens of Lawrence, it is necessary to remember that in the early days of the settlement it was a dusty and muddy place with only local plants and trees to decorate the landscape. These plants and trees were far different from the luxurious foliage to which many of the settlers from the Northeast had grown accustomed back home. The temptation to find more familiar and more richly colored plants and trees, reminiscent of the Lawrencians' former homes, was great. And it was precisely this temptation, offered in the pages of glossy, chromolithographed catalogues, which helped to set the stage for the "great Kansas seed swindle."

During the Winter and Spring of 1885, a group of strangers began to appear in Lawrence. They claimed to be agents of prominent Eastern nurseries. They were elegantly dressed down to black kid gloves and carried with them brightly colored catalogues with "painted" specimens of their wares to delight the eyes of their would-be customers. ${ }^{4}$ And, oh, the wonders which they had on offer. They had raspberry bushes which combined "the properties of both grape-vine and raspberry" costing only a dollar. ${ }^{5}$ They had an "'ever-blooming rose bush,' warranted to bloom perpetually and forever," for only two dollars each. ${ }^{6}$ Their sales methods were sophisticated and based upon the common prejudice of the day. A salesman would arrive at a residence with catalogue in hand, having timed his arrival to coincide with the male resident's absence, on the

3. On the development of chromolithography, see DAVID R. MARZIO, THE DEMOCRATIC ART: PICTURES FOR A 19TH-CENTURY AMERICA 1-22 (1979).

4. Transactions of the Fifteenth Semi-Annual Meeting of the Kansas State Horticultural Society, in KANSAS HORTICULTURAL REPORT FOR THE YEAR 1885, 19 (1885) [hereinafter HORTICULTURAL REPORT].

5. Transactions of the Nineteenth Annual Meeting of the Kansas State Horticultural Society, in HORTICULTURAL REPORT, supra note 4, at 105.

6. Id. 
assumption that women would be more gullible than men. They would show the catalogue and proclaim the glories of the goods. They would then clinch the sale and promise delivery in a few days. When delivery time arrived, a second "nursery agent" would appear with the promised seeds and seedlings and collect payment. Then both men would disappear from Kansas, never to ply their trade in the state. ${ }^{7}$ By the time the seeds had been planted and germination was due, the men were long gone but not forgotten. According to contemporary accounts, the plants rarely lived up to expectations, if they lived at all. ${ }^{8}$

But contemporary prejudices aside, it was not only the ladies of Lawrence who were taken in by the "featherless bipeds calling themselves nursery agents," as one local referred to them. ${ }^{9}$ In fact, these nursery agents also deceived the hardy, experienced farmers of Kansas and had been doing so for some years.

Why would a farmer fall for such nonsense? The claims these agents made about farming plant stock were as fantastic as those made about perpetually blooming rose bushes. They offered four varieties of apple trees guaranteed to resist borers; they sold plum trees guaranteed to be resistant to the dreaded curculio. ${ }^{10}$ Most claimed that their wares came from Russia and warranted that these Russian plants would thrive in the Kansas climate. A few were daring enough to represent local nurseries, including one from Topeka. " Of course, they did not.

Whatever their appeal, these traveling agents became a growing plague by 1885 , so much that they may well have cost Kansas farmers more than the plant vermin their plants promised to resist. This "plague of agents" dated back almost a decade at least. The Louisburg Herald, from Miami County, Kansas, ran an article on November 29, 1877 recounting the problems such agents had been causing. ${ }^{12}$ An out-of-state nursery, Shinn \& Co. of Ohio had been selling trees to the citizens of Paola. Among the trees offered up to the locals were "wild goose plums" at seventy-five cents per tree. Unfortunately the trees were not "as represented" and, further, better trees of the same variety were available from the local nursery run by Mr. Cadwallader, for only thirty-five cents each. According to the reporter, one of the locals, Mr. D.W. Lee, of Wea Township, had actually consulted a lawyer in contemplation of bringing

7. Id.

8. Id. at $107-08$.

9. Id. at 105 .

10. Id. at $106-07,168$.

11. Id. at 107 .

12. The Fruit Tree Fraud, W. HoME J., Dec. 13, 1877, at 2. 
a suit against Shinn \& Co. His lawyer, however, counseled him against such an action and told him simply to "go his way and sin no more."13

Even if Mr. Lee learned his lesson in 1877, many of his fellow farmers in Eastern Kansas had not. Certainly, the out-of-state nursery agents were still invading Eastern Kansas in ever greater numbers. ${ }^{14} \mathrm{~A}$ complaint from a Mr. Goddard of Minneapolis, in Ottawa County, is typical:

Every farmer that they canvassed for orders would be a witness against them. My three nearest neighbors are willing to swear that Carroll (the agent for N.H. Albaugh, Tadmore, Ohio,) stated the stocks were imported from Russia; and I traced $\$ 75$ worth of trees that he sold to a few men who heard him in Minneapolis offer to bet $\$ 50$ against the same amount from Barnes's agent here, that Carroll could produce the bill of lading from a German port for 750,000 Russian stocks. Barnes's agents backed down, and when $C$. called on the 'tender-foots' he gathered them right in. At the lowest estimate they will take out of the county $\$ 5,000$. They have all left now, with the intention of working Davis county. Saline county was finished before they stuck here. ${ }^{15}$

Why were these eastern "tree-peddlers" and nursery agents so successful in Kansas? Obviously they were professional confidence men. But there was more to it. In fact, what these men offered the housewives and farmers of Kansas was the promise of new plants and trees that could withstand the rigors and changeability of the Kansas climate. $^{16}$ Most of the settlers of Kansas in the 1870 s and 1880 s could still remember the homes from which they had emigrated, mostly from the East. ${ }^{17}$ They were still attempting to find plants and trees which could produce better yields and a more comforting (i.e. more like that of the East) home environment than they had thus far found in Kansas. This was precisely what these agents promised. The use of glossy catalogues and specimen plants ${ }^{18}$ simply made the offers more seductive.

13. Id.

14. See Transactions of the Nineteenth Annual Meeting of the Kansas State Horticultural Society, supra note 5, at 106-07 (1886) (detailing encounters with out-of-state nursery agents).

15. Id.

16. See id. at 90 (discussing need for trees that withstand the extremes of changing temperatures in Kansas); see also William Cutter, Hardy Fruits for Kansas, in HoRTiCULTURAL REPORT, supra note 4, at 54 (discussing fruits that are not hardy enough to survive in Kansas). Unfortunately, it would seem that many Kansans believed that the climate was colder, and thus more suitable to the so-called Russian varietals, than it was.

17. Some, of course, had migrated from England, Ireland, Scotland, or Germany, where the climate was easier on farmers as a general rule.

18. P.C. Bowen, Horticulture in Southern Kansas, in HORTICULTURAL REPORT, supra note 4, at 14. Some agents even displayed specimens in glass jars. Id. 
By 1885 the extent of the financial losses caused by these dishonest plant and tree agents had led both to media coverage and to the involvement of both the Kansas Horticultural Society and the Kansas legislature. The legislation enacted by the legislature was only one part of the action taken. The Kansas Horticultural Society devoted a significant part of its 1886 meeting to discussing the problem of these out-of-state agents and concluded that one partial solution to these problems was to encourage Kansas residents to better educate themselves on horticulture by attending Society meetings and by forming local horticultural societies. ${ }^{19}$

A second part of the solution was suggested by the reporter who wrote the article in the Louisburg Herald:

There is hardly a county in Kansas, at least in the eastern portion, which does not contain one or more good nurseries at which farmers can procure native-grown trees .... Home-grown trees are hardier, more likely to live, better adapted to our climate, and of better varieties for Kansas than foreign grown. Besides, our nurserymen have their reputations to preserve. As a rule, buy fruit trees of a man whom you know. ${ }^{20}$

It is difficult to know at so distant a time from the occurrences whether the combination of education, media attention, and criminal legislation put an end to the seed swindles of the 1870s and 1880s. Certainly, they did not put an end to the sale of seed and plants by glossy catalogues, which continue to this day to entrance and entrap Kansans in search of ever better plants and trees with which to fill their gardens and farms.

19. Id. at 15. Interestingly, the Douglas County Horticultural Society had been organized in 1872 and held its first show in October of that year. It is also of interest that many of the exhibitors at this show were men, including Judge Christian, in whose courtroom the show took place. See First Exhibition of the Douglas County Society, W. HoME J., Oct. 31, 1872, at 3.

20. The Fruit Tree Fraud, supra note 12, at 3. 
**** 